\title{
Article \\ Community Assembly and Co-Occurrence Patterns of Microeukaryotes in Thermokarst Lakes of the Yellow River Source Area
}

\author{
Ze Ren ${ }^{1,2, * \mathbb{D}}$, Kang Ma ${ }^{2}$, Xuan Jia ${ }^{3}$, Qing Wang ${ }^{1,2}$, Cheng Zhang ${ }^{1,4}$ and Xia Li ${ }^{1,2}$ \\ 1 Research and Development Center for Watershed Environmental Eco-Engineering, \\ Advanced Institute of Natural Sciences, Beijing Normal University, Zhuhai 519087, China; \\ wq@bnu.edu.cn (Q.W.); zhangcheng@bnu.edu.cn (C.Z.); lixiabnu@bnu.edu.cn (X.L.) \\ 2 School of Environment, Beijing Normal University, Beijing 100875, China; mk@mail.bnu.edu.cn \\ 3 College of Education for the Future, Beijing Normal University, Zhuhai 519087, China; \\ 202011039306@mail.bnu.edu.cn \\ 4 School of Engineering Technology, Beijing Normal University, Zhuhai 519087, China \\ * Correspondence: renzedyk@gmail.com
}

check for

updates

Citation: Ren, Z.; Ma, K.; Jia, X.;

Wang, Q.; Zhang, C.; Li, X.

Community Assembly and

Co-Occurrence Patterns of

Microeukaryotes in Thermokarst

Lakes of the Yellow River Source

Area. Microorganisms 2022, 10, 481.

https://doi.org/10.3390/

microorganisms10020481

Academic Editor: O. Roger Anderson

Received: 25 January 2022

Accepted: 17 February 2022

Published: 21 February 2022

Publisher's Note: MDPI stays neutral with regard to jurisdictional claims in published maps and institutional affiliations.

Copyright: (c) 2022 by the authors. Licensee MDPI, Basel, Switzerland. This article is an open access article distributed under the terms and conditions of the Creative Commons Attribution (CC BY) license (https:/ / creativecommons.org/licenses/by/ $4.0 /)$.

\begin{abstract}
Thermokarst lakes are important aquatic ecosystems in cold regions, experiencing several changes due to global warming. However, the fundamental assembly mechanisms of microeukaryotic communities in thermokarst lakes are unknown. In this study, we examined the assembly processes and co-occurrence networks of microeukaryotic communities in sediment and water of thermokarst lakes in the Yellow River Source Area. Sediment microeukaryotic communities had a significantly lower $\alpha$-diversity but higher $\beta$-diversity than water microeukaryotic communities. $\mathrm{pH}$, sediment organic carbon, and total phosphorus significantly affected taxonomic and phylogenetic diversity of sediment communities, while conductivity was a significant driver for water communities. Both sediment and water microeukaryotic communities were strongly governed by dispersal limitation. However, deterministic processes, especially homogenous selection, were more relevant in structuring microeukaryotic communities in water than those in sediment. Changes in total nitrogen and phosphorus in sediment could contribute to shift its microeukaryotic communities from homogeneous selection to stochastic processes. Co-occurrence networks showed that water microeukaryotic communities are more complex and interconnected but have lower modularity than sediment microeukaryotic communities. The water microeukaryotic network had more modules than the sediment microeukaryotic network. These modules were dominated by different taxonomic groups and associated to different environmental variables.
\end{abstract}

Keywords: microeukaryotes; deterministic process; stochastic process; co-occurrence; Qinghai-Tibet Plateau

\section{Introduction}

Thermokarst lakes are shallow thaw lakes formed after the thawing of ice-rich permafrost and widely distributed in cold regions with high altitude or latitude [1,2]. In the Arctic and sub-Arctic regions, as well as the Qinghai-Tibet Plateau (QTP), thermokarst lakes are common landscape features [3-5]. Thermokarst lakes show huge differences in lake size ranging from a few square meters to hundreds of square kilometers [6-8]. Moreover, thermokarst lakes also have significantly different geomorphological, physicochemical, and biological characteristics, even at a very small spatial scale [5,9-11]. Permafrost degradation continuously drives the evolution of thermokarst lakes in terms of their formation, expansion, shrinkage, and, finally, disappearance [12-14]. Accelerating climate change expedites the evolution processes of thermokarst lakes, leading to tremendous changes in lake environments and ecosystem processes [8] and exerting pressure on the organisms living in them. However, the fundamental mechanisms of community assembly in thermokarst 
lakes are still unknown and are important to understanding ecosystem stability and the function of thermokarst lakes in a warming world.

Microeukaryotic communities are a versatile component in lake ecosystems and encompass enormous diversity [15-17]. Composed by algae, fungi, protozoa, and metazoa through complex interactions $[18,19]$, microeukaryotic communities play important roles in structuring the food web of aquatic ecosystems, and their assembly mechanisms and environmental responses have long been of research interest in microbial ecology [20-22]. Microeukaryotic community structure vary across different temporal and spatial scales $[17,21,23,24]$. Understanding the assembly rules controlling community diversity and biogeography is central in microbial ecology [25,26]. Microbial community is simultaneously influenced by stochastic and deterministic processes with differential importance [25-27]. Deterministic processes emphasize the importance of niche-based mechanisms, such as environmental filtering and biotic interactions [26]. On the contrary, stochastic processes highlight neutral processes, such as unpredictable disturbances, ecological drift, and probabilistic dispersal [28-30]. However, it is challenging to characterize those processes in microbial community variations [29,31,32]. In addition, according to the topological features of the interactions between taxa, co-occurrence networks reveal community assembly rules $[33,34]$ by disentangling interactions in the microbiome, delineating keystone taxa, and finding modular structures [35,36]. For thermokarst lakes, we lack an understanding on microbial community assembly mechanisms.

In general, sediment and water are different in various aspects but also have intimate interconnections $[37,38]$. In thermokarst lakes, the sediment-water interactions were inherent from the lake formation and intensified by thermokarst processes, microbial activities, and wind-induced mixing [39-41]. Our previous studies of thermokarst lakes showed that sediment and water harbor distinct bacterial communities in terms of taxonomic composition, beta diversity, and co-occurrence networks [11,42]. Thus, it is also interesting to reveal the differences of community assembly rules between sediment and water microeukaryotic communities.

As the "Third Pole" of the Earth, QTP is extremely sensitive to anthropogenic activities and global climate change [43,44]. In the Yellow River Source Area (YRSA), it is predicted that the mean annual temperature will increase $1.8-3.5^{\circ} \mathrm{C}$ by 2080 [45]. The ongoing global warming has already accelerated permafrost degradation, resulting in extensive changes of thermokarst lakes [8,46]. In this study, we investigated microeukaryotes in 23 thermokarst lakes in the YRSA on the QTP using $18 \mathrm{~S}$ rRNA gene sequencing. We aimed to (1) assess the relative contribution of stochastic and deterministic processes in shaping microeukaryotic communities in sediment and water in the thermokarst lakes, and (2) disentangle the co-occurrence patterns of these microeukaryotic communities. The results can provide useful information for a better understanding and response prediction of thermokarst lakes in a warming future.

\section{Methods}

\subsection{Study Area, Field Sampling, and Chemical Analyses}

This study was conducted in the Yellow River Source Area, located in the northeast of the QTP (Figure S1). This area has a cold and semiarid climate with an annual precipitation of 300-800 $\mathrm{mm}$ [47], an annual mean air temperature between -4 and $2{ }^{\circ} \mathrm{C}$ [47], and annual evaporation of $800-1200 \mathrm{~mm}$ [48]. The average elevation is about $4500 \mathrm{~m}$ [4]. Permafrost and thermokarst lakes are widely distributed in this area [4,49], with permafrost covering up to $80 \%$ of the land [4].

In early July 2020, 23 thermokarst lakes were sampled in this area. Information on the lakes and sampling process has been provided in our previous publication [11]. In each lake, both water samples and sediment samples were collected with three replicates (subsamples). Thus, a total of 23 water samples and 23 sediment samples were collected. In each lake, three $1 \mathrm{~L}$ water subsamples were collected at a depth of 0.3 to $0.5 \mathrm{~m}$ and filled in acid clean bottles. Water microbial samples were collected by filtering $200 \mathrm{~mL}$ 
water from each of the three $1 \mathrm{~L}$ subsamples, respectively. For each lake, three filters were combined into one composite sample and frozen in liquid nitrogen immediately in the field and stored at $-80^{\circ} \mathrm{C}$ in the lab until DNA extraction. The remaining water was used for chemical analyses in the lab. The conductivity and $\mathrm{pH}$ of the lake water were measured in situ using a multiparameter instrument (YSI ProPlus, Yellow Springs, $\mathrm{OH}$, USA). For water samples, dissolved organic carbon (DOC), total nitrogen (TN), and total phosphorus (TP) were analyzed. DOC was analyzed on filtered (using pre-combusted GF/F filters) lake water using a Shimadzu TOC Analyzer (Shimadzu, Columbia, MD, USA). TN was measured by ion chromatography after persulfate oxidation (EPA 300.0). TP was measured using the ascorbic acid colorimetric method after persulfate oxidation (EPA 365.3). In each lake, sediment samples were collected using a Ponar Grab sampler from three points (subsamples). For each subsample, the top $5 \mathrm{~cm}$ of the sediment was collected and homogenized. For each lake, sediment microbial sample was collected by mixing three $15 \mathrm{~mL}$ subsamples in a $45 \mathrm{~mL}$ sterile centrifuge tube and freezing it in liquid nitrogen in the field. The remaining sediments were used for chemical analyses in the lab. For sediment samples, $\mathrm{pH}$, conductivity, sediment organic carbon (SOC), TN, and TP were analyzed. SOC was measured by the potassium dichromate oxidation spectrophotometric method (Chinese standard method HJ615-2011). Sediment TN was measured using the modified Kjeldahl Method (Chinese standard method HJ717-2014). Sediment TP was measured using the ascorbic acid colorimetric method after microwave extraction with nitric acid [50]. Chemical properties of sediment and water samples were summarized in our previous study [11].

\subsection{DNA Extraction, $P C R$, and Sequencing}

DNA was extracted using the TIANGEN-DP336 DNA Isolation Kit (TIANGEN-Biotech, Beijing, China) following the manufacturer's instructions. DNA extracts were quantified using a Qubit 3.0 Fluorometer (Life Technologies, Darmstadt, Germany). A total of 50-100 ng DNA was used to generate amplicons. The $18 \mathrm{~S}$ rDNA hypervariable regions V4-V5 were amplified using forward primers 817F-5' ${ }^{\prime}$-TTAGCATGGAATAATRRAATAGGA- $3^{\prime}$ and reverse primer 1196R-5'-TCTGGACCTGGTGAAGTTTCC-3'. The PCR reaction was conducted on a thermal cycler (ABI GeneAmp ${ }^{\circledR}$ 9700,Foster City, CA, USA) using the following program: $5 \mathrm{~min}$ initial denaturation at $94{ }^{\circ} \mathrm{C}, 30 \mathrm{~s}$ denaturation at $94{ }^{\circ} \mathrm{C}$ with 26 cycles, $30 \mathrm{~s}$ annealing at $56^{\circ} \mathrm{C}, 20 \mathrm{~s}$ extension at $72{ }^{\circ} \mathrm{C}$, and finally 5 min extension at $72{ }^{\circ} \mathrm{C}$. DNA libraries were verified on $2 \%$ agarose gels (Biowest agarose, Madrid, Spain) and quantified using a Qubit 3.0 Fluorometer (Life Technologies, Germany). DNA libraries were multiplexed and loaded on an Illumina MiSeq platform according to the manufacturer's instructions (Illumina, San Diego, CA, USA). Raw sequence data were analyzed using QIIME 1.9.0 [51]. Sequences were quality filtered and clustered to generate operational taxonomic units (OTUs) at a threshold of $97 \%$ similarity against the SILVA 132 database [52] using QIIME. Raw sequence data can be accessed at the China National Center for Bioinformation (PRJCA005279).

\subsection{Analyses}

A null model analysis was used to estimate assembly processes of microeukaryotic communities in sediment and water of the thermokarst lakes using the picante v1.8.2 package in R [53]. Turnover in phylogenetic composition between communities was quantified using beta mean nearest taxon distance ( $\beta$ MNTD). The influence of deterministic processes (heterogeneous selection and homogeneous selection) on community assembly was estimated by evaluating the difference between the observed $\beta$ MNTD and the mean of the null distribution of $\beta$ MNTD in units of standard deviation, which is the beta nearest taxon index $(\beta N T I)$. $\beta$ NTI values $<-2$ or $>+2$ indicate less than or greater than expected phylogenetic turnover, representing signals for heterogeneous selection and homogenous selection, respectively [25]. On the other hand, if $-2<\beta N T I<2$, compositional differences are explained by stochastic processes (dispersal limitations and homogenizing dispersal). To assess the 
relative influences of the processes not assigned to deterministic processes, a Raup-Crick metric of taxonomic $\beta$-diversity ( $\mathrm{RC}_{\text {Bray }}$ ) was used to analyze pairwise comparisons of the observed and expected taxonomic turnover (at OTU level) between communities. The fraction of pairwise comparisons with $-2<\beta \mathrm{NTI}<2$ and $\mathrm{RC}_{\mathrm{Bray}}<-0.95$ were attributed to homogeneous dispersal, while those with $-2<\beta \mathrm{NTI}<2$ and $\mathrm{RC}_{\text {Bray }}>0.95$ were attributed to dispersal limitation. Pairwise comparisons falling within null distribution of both metrics of phylogenetic and taxonomic $\beta$-diversity $\left(-2<\beta \mathrm{NTI}<2\right.$ and $\left.-0.95<\mathrm{RC}_{\mathrm{Bray}}<0.95\right)$ were assigned to "undominated", representing the fraction that was not strongly governed by any single process $[25,26]$.

Co-occurrence networks of sediment and water microeukaryotic communities were constructed by pairwise correlations (Spearman correlation) between OTUs. OTUs with an average relative abundance $>0.01 \%$ and present in more than 6 samples were used. $p$-values of Spearman correlation were corrected using the FDR method [54]. Only strong (Spearman's $\mathrm{R}>0.6$ or $\mathrm{R}<-0.6$ ) and significant $(p<0.01)$ correlations were used in network construction. Meanwhile, random networks (permutation $=999$ ) with the same number of nodes and edges as the community networks investigated in this study were generated using the Erdos-Renyi model with the igraph 1.2.6 package [55]. Topological parameters such as average degree (average number of neighbors for all nodes, explaining complex pairwise connection), clustering coefficient (a measure of the local connectivity associating to network robustness), average path length (the average shortest path lengths connecting the node to all other nodes), and graph density as well as modular structure of the networks were analyzed using the igraph package. Differences of topological parameters between the sediment microeukaryotic network (SMN) and the water microeukaryotic network $(\mathrm{WMN})$ were assessed using $t$-test (different low case letters indicate a significant difference of $p<0.05)$.

$\alpha$-diversity indices, including Chao 1 , observed OTUs, Shannon, and phylogenetic diversity (PD whole tree) were calculated using QIIME 1.9.1 [51]. $\beta$-diversity in terms of taxonomic and phylogenetic turnover was assessed using Bray-Curtis distance (based on the relative abundance of OTUs) and $\beta$ MNTD, respectively. To estimate the habitat niche occupied by each species, we calculated the Levins niche width [56] using the "spaa" package [57] in R. The formula is $B_{i}=1 / \sum_{1}^{n} p_{i}^{2}$. $B_{i}$ represents the niche width of $\mathrm{OTU}_{\mathrm{i}}$ across the communities, $n$ is the total number of communities, and $p_{i}$ is the proportion of $\mathrm{OTU}_{\mathrm{i}}$ in each community. Species with a higher niche width are distributed more evenly along a wider habitat range than those with a lower niche width. Differences of $\alpha$-diversity and $\beta$-diversity between sediment and water samples were assessed using a Wilcoxon rank-sum test. Principal coordinates analysis ( $\mathrm{PCoA})$ was performed to assess differences of microeukaryotic communities between sediment and water samples based on Bray-Curtis distance and $\beta M N T D$. Mantel tests were conducted to test the relationships between environmental variables and microeukaryotic community properties, including $\beta N T I, \beta M N T D$, Bray-Curtis distance, major network modules (modules with more than 30 nodes), and major taxonomic groups. All statistical analyses were carried out in R 4.0.5 [58].

\section{Results}

\subsection{General Patterns of Microeukaryotic Communities in Sediment and Water}

After quality filtering, a total of 2,032,004 high-quality sequences were obtained and clustered into 3141 OTUs. However, only 6 OTUs were found in all samples (Figure S2). Alpha diversity indexes (observed OTUs, Chao1, and phylogenetic diversity) were significantly lower in sediment samples than in water samples, except for the Shannon Index (Figure 1a). However, taxonomic $\beta$-diversity (shown as the Bray-Curtis distance) and phylogenetic $\beta$-diversity (shown as $\beta$ MNTD) were significantly higher in sediment samples than in water samples (Figure 1b). 
(a)
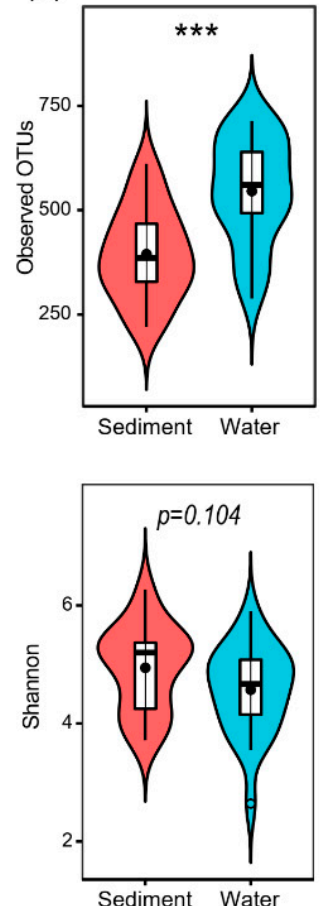
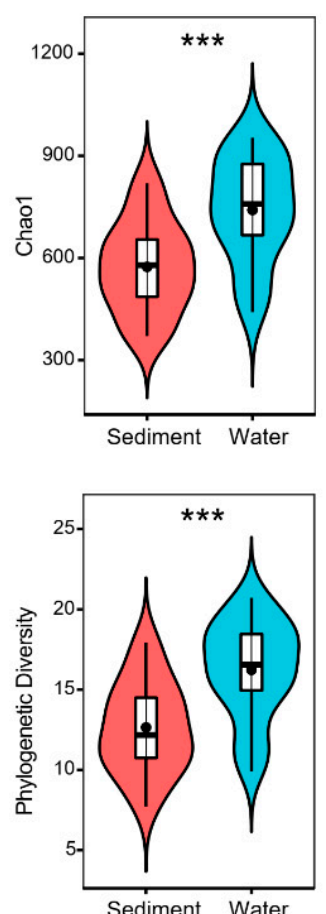

(b)
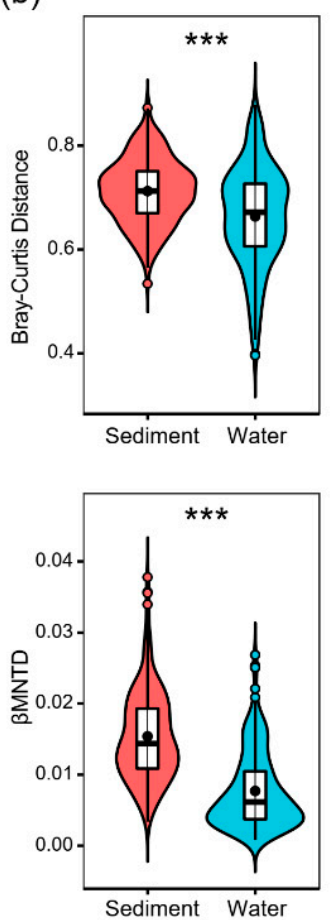

(c)
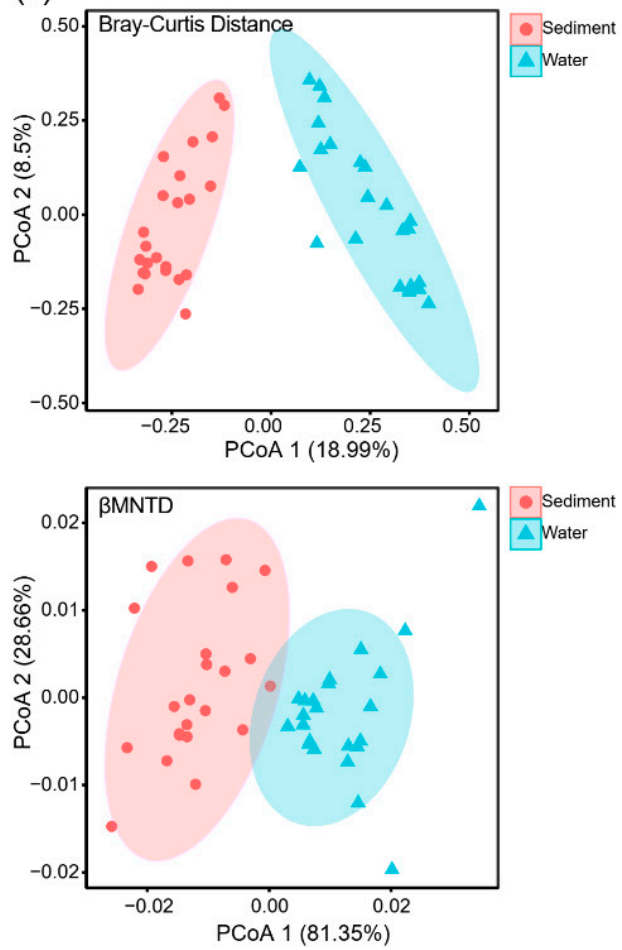

Figure 1. Distinct patterns of microeukaryotic communities in sediment and water samples. (a) Alpha diversity. (b) Beta-diversity. The differences of diversity indexes between sediment and water samples were tested using Wilcoxon rank-sum test $\left({ }^{* * *} p<0.001\right)$. (c) Principal coordinates analysis (PCoA) based on Bray-Curtis distance and $\beta$ MNTD.

Microeukaryotic communities also showed a distinct composition between sediment and water samples. Principal coordinates analysis (PCoA) based on Bray-Curtis distance and $\beta$ MNTD indicated that microeukaryotic community composition was significantly different between sediment and water samples (Figure 1c). The phylogenetic diversity of microeukaryotic OTUs covered 11 supergroups (Figure 2a). Opisthokonta, Cryptophyceae, and SAR (Stramenopiles-Alveolata-Rhizaria) were dominant (mean relative abundance $>5 \%$ ) in both sediment and water samples (Figure 2a). In sediment samples, Fungi and Ciliophora were the dominant lineages with a mean relative abundance of $58.9 \%$ and $6.4 \%$, respectively (Figure 2b). In water samples, however, Fungi, Cryptomonas sp., and Choanoflagellida were the dominant lineages with a mean relative abundance of $31.5 \%$, $8.6 \%$, and $6.9 \%$, respectively (Figure $2 b$ ).

To identify physicochemical properties that affect dissimilarities of microeukaryotic communities and major lineages, we correlated these values to the differences in physicochemical properties between each pairwise set of samples (Tables 1 and 2). For sediment samples, $\mathrm{pH}, \mathrm{SOC}$, and TP were strong and positive predictors for dissimilarities of microeukaryotic communities as well as many major lineages (Table 1). For water samples, however, conductivity and DOC were strong predictors for community dissimilarities and many major lineages (Table 2). 

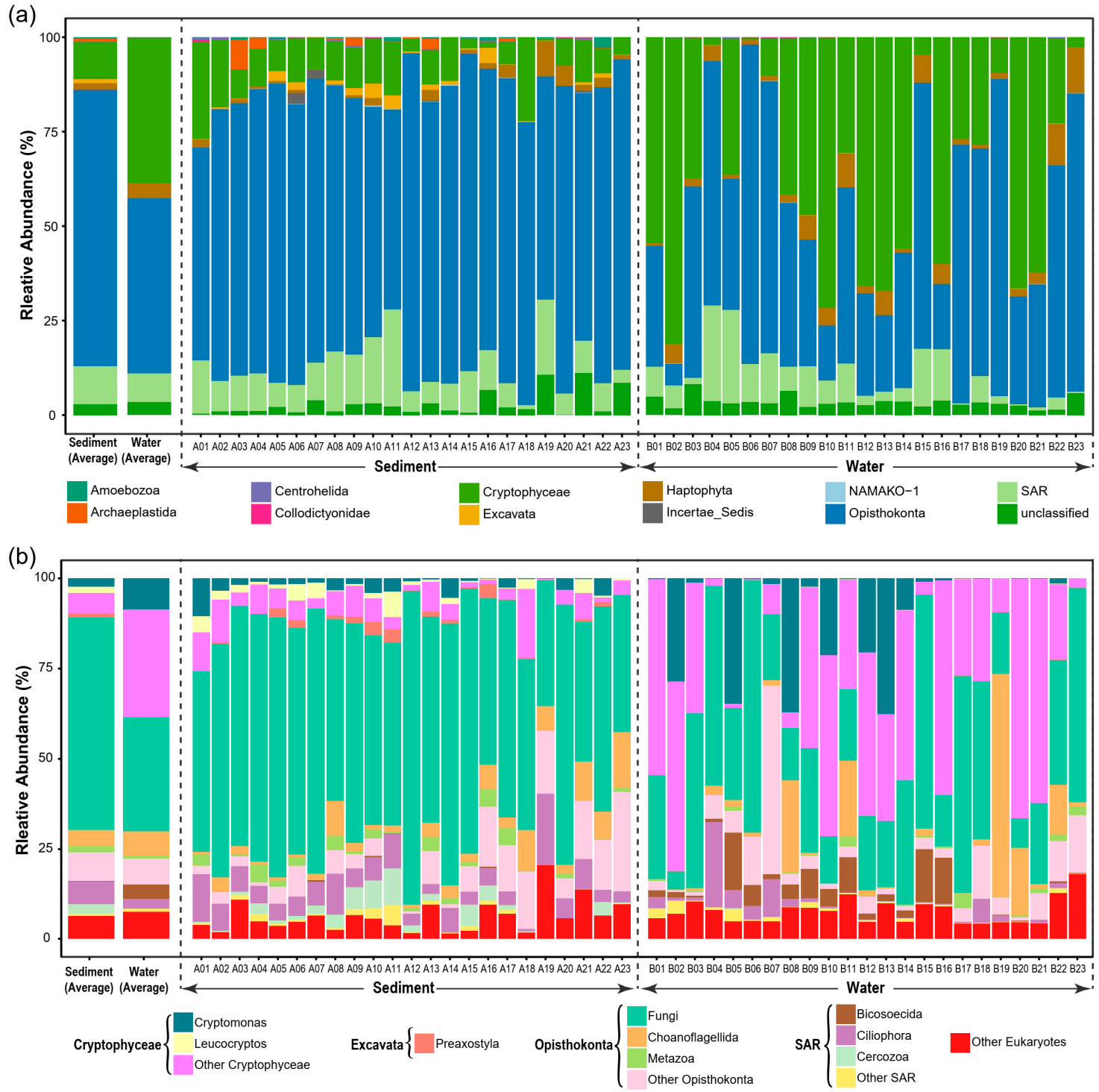

Figure 2. Taxonomic composition of the microeukaryotic communities in sediment and water samples. (a) Relative abundance of the super groups. (b) Relative abundance of the major lineages of the super groups.

Table 1. Mantel test between environmental variables and sediment microeukaryotic communities. Significant correlations $(p<0.05)$ were shown in bold with ${ }^{*}$ and ${ }^{* *}$ represent $p<0.05$ and $p<0.01$, respectively. NA represents not applicable.

\begin{tabular}{|c|c|c|c|c|c|}
\hline & $\mathrm{pH}$ & Conductivity & SOC & TN & TP \\
\hline$\beta \mathrm{NTI}$ & -0.041 & 0.075 & 0.115 & $0.175 * *$ & $0.137 *$ \\
\hline$\beta$ MNTD & $0.197 * *$ & 0.084 & $0.145 *$ & 0.116 & 0.146 * \\
\hline Bray-Curtis Distance & $0.250 * *$ & -0.026 & $0.173 * *$ & 0.052 & $0.248 * *$ \\
\hline Module1 & $0.130 *$ & 0.040 & $0.255 * *$ & 0.107 & $0.358 * *$ \\
\hline Module2 & -0.016 & 0.067 & -0.079 & -0.035 & 0.071 \\
\hline Cryptomonas sp. & -0.015 & 0.074 & $0.223 * *$ & $0.131 *$ & 0.236 ** \\
\hline Leucocryptos sp. & $0.138 *$ & -0.112 & -0.051 & 0.006 & 0.068 \\
\hline Preaxostyla & -0.069 & $0.208^{* *}$ & -0.078 & -0.028 & -0.088 \\
\hline Fungi & $0.190 * *$ & -0.039 & $0.152 *$ & 0.058 & $0.233^{* *}$ \\
\hline Choanoflagellida & 0.043 & 0.039 & -0.119 & -0.091 & 0.004 \\
\hline Metazoa & $0.198 * *$ & $0.187 * *$ & 0.056 & 0.069 & 0.127 * \\
\hline Bicosoecida & NA & NA & NA & NA & NA \\
\hline Ciliophora & 0.122 & -0.03 & $0.188 * *$ & 0.029 & $0.228 * *$ \\
\hline Cercozoa & $0.172 * *$ & $0.165 * *$ & 0.037 & 0.098 & $0.281 * *$ \\
\hline
\end{tabular}


Table 2. Mantel test between environmental variables and water microeukaryotic communities. Significant correlations $(p<0.05)$ were shown in bold with * and ${ }^{* *}$ represent $p<0.05$ and $p<0.01$, respectively. NA represents not applicable.

\begin{tabular}{|c|c|c|c|c|c|}
\hline & $\mathrm{pH}$ & Conductivity & DOC & TN & TP \\
\hline$\beta N T I$ & -0.023 & 0.011 & -0.116 & 0.023 & 0.023 \\
\hline$\beta M N T D$ & -0.041 & 0.134 * & 0.067 & -0.007 & -0.004 \\
\hline Bray-Curtis Distance & 0.071 & 0.144 * & $0.183 * *$ & -0.031 & -0.034 \\
\hline Module1 & 0.118 & 0.063 & $0.129 *$ & -0.104 & -0.091 \\
\hline Module2 & 0.126 * & $0.480 * *$ & $0.342 * *$ & $0.155 *$ & $0.267 * *$ \\
\hline Module3 & $-0.153 *$ & -0.043 & 0.021 & -0.113 & 0.112 \\
\hline Module4 & -0.001 & $0.321 * *$ & 0.105 & 0.065 & $0.208 * *$ \\
\hline Module5 & 0.082 & 0.032 & -0.044 & 0.048 & -0.063 \\
\hline Module6 & $0.192 * *$ & 0.011 & -0.015 & 0.122 & 0.142 * \\
\hline Module7 & 0.052 & $0.178 * *$ & $0.142 *$ & -0.042 & -0.005 \\
\hline Cryptomonas sp. & 0.008 & $0.156 *$ & $0.133 *$ & -0.034 & 0.004 \\
\hline Leucocryptos sp. & -0.029 & $0.373 * *$ & $0.170 *$ & -0.057 & -0.021 \\
\hline Preaxostyla & NA & NA & NA & NA & NA \\
\hline Fungi & 0.089 & 0.085 & 0.079 & 0.019 & 0.125 * \\
\hline Choanoflagellida & 0.112 & 0.097 & 0.101 & $0.406 * *$ & $0.203 * *$ \\
\hline Metazoa & 0.032 & 0.115 & 0.038 & 0.006 & 0.023 \\
\hline Bicosoecida & 0.092 & $0.458 * *$ & $0.347 * *$ & 0.040 & $0.332 * *$ \\
\hline Ciliophora & $-0.155 *$ & 0.045 & -0.011 & $-0.144 *$ & 0.121 \\
\hline Cercozoa & 0.004 & -0.030 & -0.032 & 0.071 & -0.088 \\
\hline
\end{tabular}

\subsection{Assembly Processes}

The quantification of phylogenetic turnover showed that stochastic processes (homogenizing dispersal and dispersal limitation) was dominant in both sediment (59.3\%) and water $(60.9 \%)$ microeukaryotic communities (Figure 3). Dispersal limitation contributed the most in the stochastic assembly. Deterministic assembly (homogeneous selection and heterogeneous selection) was much higher in water $(29.2 \%)$ microeukaryotic communities than in sediment $(7.1 \%)$ microeukaryotic communities (Figure 3).
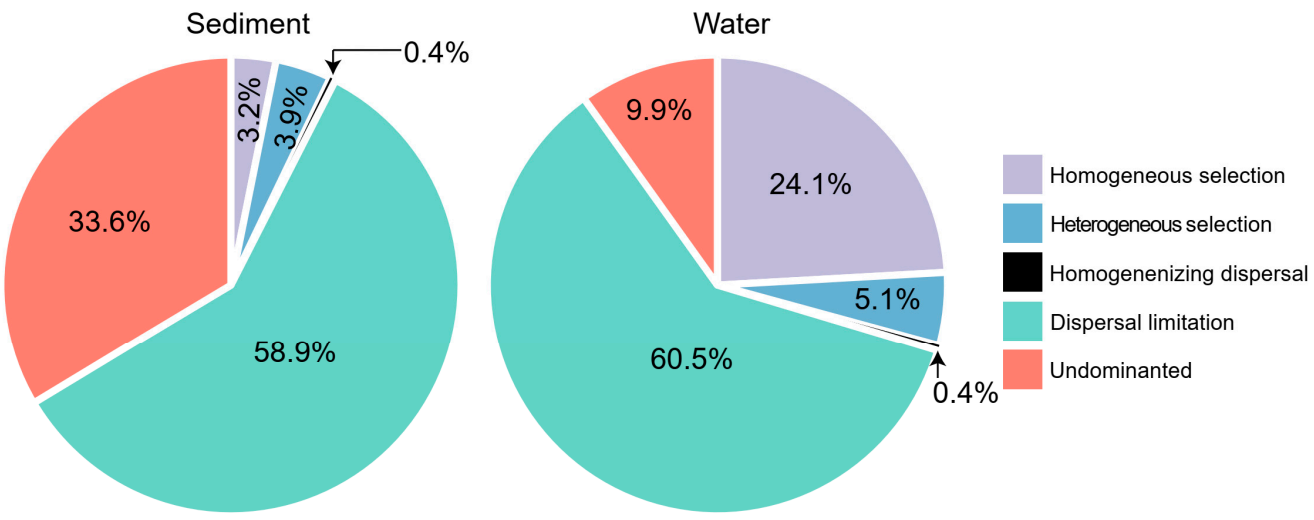

Figure 3. The contribution of deterministic (homogeneous and heterogeneous selection) and stochastic (dispersal limitations and homogenizing dispersal) processes to the turnover in the assembly of sediment and water microeukaryotic communities in thermokarst lakes. "Undominated" represents the fraction that was not dominated by any single process.

The relationships between $\beta$ NTI and major environmental variables were used to estimate changes in the relative influences of deterministic and stochastic assembly processes. Mantel tests showed that TN and TP were the best predictors of assembly processes for sediment microeukaryotic communities (Table 1). Pairwise $\beta$ NTI values for sediment microeukaryotic communities were significantly and positively correlated with differences in TN and TP (Table 1), suggesting that an increasing divergence of TN and TP could 
contribute to a shift from homogeneous selection to stochastic assembly and finally to heterogeneous selection in the assembly of sediment microeukaryotic communities. However, none of the tested environmental variables had significant relationships with $\beta$ NTI of water microeukaryotic communities (Table 2).

\subsection{Co-Occurrence Networks}

We generated co-occurrence networks for sediment and water microeukaryotic communities based on pairwise correlations. The sediment microeukaryotic network (SMN) was composed by 284 OTUs with 458 associations (Figure 4 and Table 3). The water microeukaryotic network (WMN) was composed by 376 OTUs with 1395 associations (Figure 4 and Table 3). A set of network-level and node-level topological features were calculated (Figure 5 and Table 3). The average degree, clustering coefficient, and graph density were higher in WMN than SMN, suggesting that OTUs in WMN were more interconnected. Moreover, the average path length and diameter were lower in WMN than in SMN, revealing closer relationships among water microeukaryotic communities. These results indicated that OTUs in water microeukaryotic communities co-occurred more frequently than that in sediment microeukaryotic communities. For the node-level topological features, the average values of eccentricity and closeness centrality were significantly higher, while degree, betweenness centrality, and clustering were significantly lower in SMN OTUs than in WMN OTUs (Figure 5).

Table 3. Comparison of topological parameters of co-occurrence networks investigated in this study (sediment microeukaryotic network and water microeukaryotic network) and their associated random networks (permutation $=999$, values shown mean \pm SD). The differences between sediment and water microeukaryotic network were assessed using $t$-test (different low case letters indicate the significant difference of $p<0.05$ ).

\begin{tabular}{|c|c|c|c|c|}
\hline \multirow{2}{*}{ Topological Parameters } & \multicolumn{2}{|c|}{ Sediment } & \multicolumn{2}{|c|}{ Water } \\
\hline & This Study & Random & This Study & Random \\
\hline Number of Nodes & 284 & 284 & 376 & 376 \\
\hline Number of Edges & 458 & 458 & 1395 & 1395 \\
\hline Negative Edges & 12 & 12 & 140 & 140 \\
\hline Average Degree & 3.225 & 3.225 & 7.420 & 7.420 \\
\hline Graph Density & 0.011 & 0.011 & 0.02 & 0.02 \\
\hline Average Path Length & $9.627^{\mathrm{a}}$ & $4.821 \pm 0.078$ & $4.730^{b}$ & $3.177 \pm 0.007$ \\
\hline Diameter & $26^{a}$ & $10.7 \pm 0.879$ & $15^{b}$ & $5.8 \pm 0.413$ \\
\hline Clustering Coefficient & $0.460^{\mathrm{a}}$ & $0.012 \pm 0.005$ & $0.528^{b}$ & $0.020 \pm 0.002$ \\
\hline Centralization Degree & $0.038^{\mathrm{a}}$ & $0.021 \pm 0.003$ & $0.063^{b}$ & $0.024 \pm 0.004$ \\
\hline Centralization Betweenness & $0.201^{\mathrm{a}}$ & $0.063 \pm 0.014$ & $0.069^{b}$ & $0.020 \pm 0.004$ \\
\hline Centralization Closeness & $0.004^{\mathrm{a}}$ & $0.013 \pm 0.004$ & $0.008^{b}$ & $0.097 \pm 0.020$ \\
\hline Modularity & $0.836^{\mathrm{a}}$ & $0.573 \pm 0.01$ & $0.639^{b}$ & $0.334 \pm 0.006$ \\
\hline
\end{tabular}

In addition, both SMN and WMN had a significant modular structure (Figure 4). SMN had a significantly higher modularity but a smaller number of nodes than WMN, suggesting that SMN was composed by more small modules than WMN (Figure 4). SMN only had 2 major modules (module with more than 30 nodes), while WMN had 7 major modules (Figure 4). These modules had different taxonomic compositions (Figure 6). A Mantel test showed that these major modules responded differently to environmental properties (Tables 1 and 2). For example, in SMN, module1 had strong correlations with $\mathrm{pH}, \mathrm{SOC}$, and TP, while module 2 did not correlate with these environmental variables (Table 1). In WMN, module2 had strong correlations with all these environmental variables while module5 did not correlate with any (Table 2). 
(a)
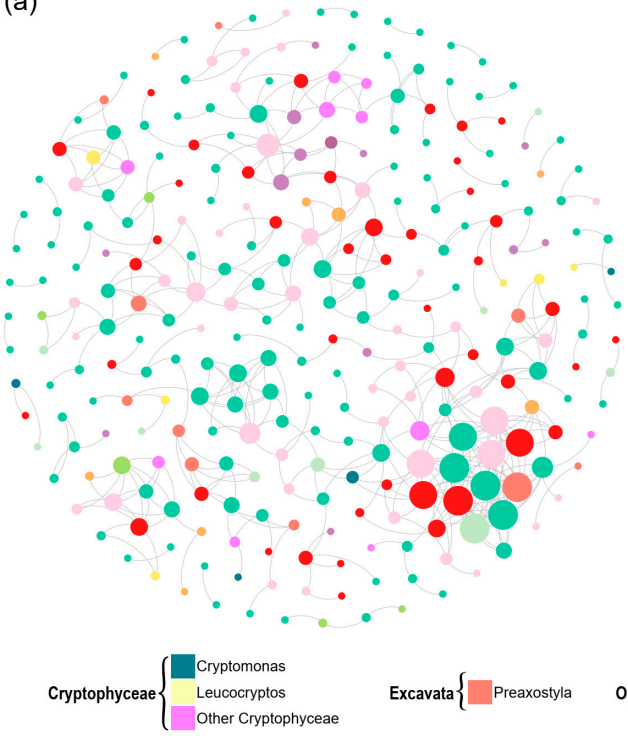

(c)

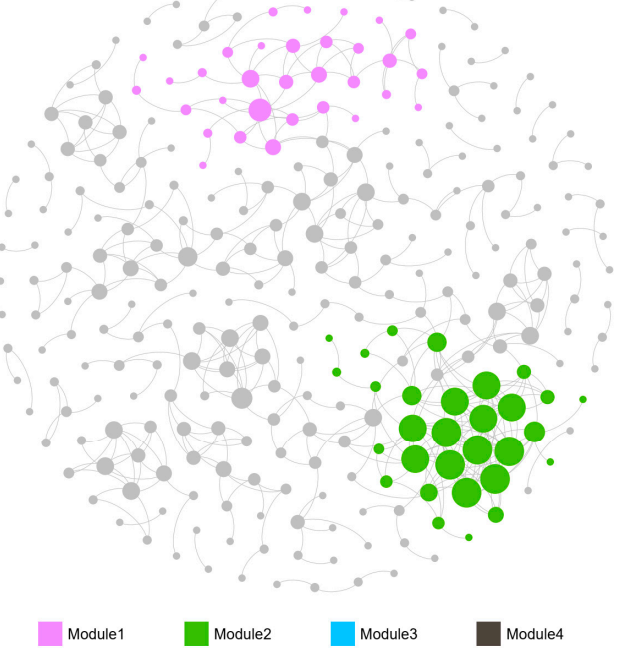

(b)

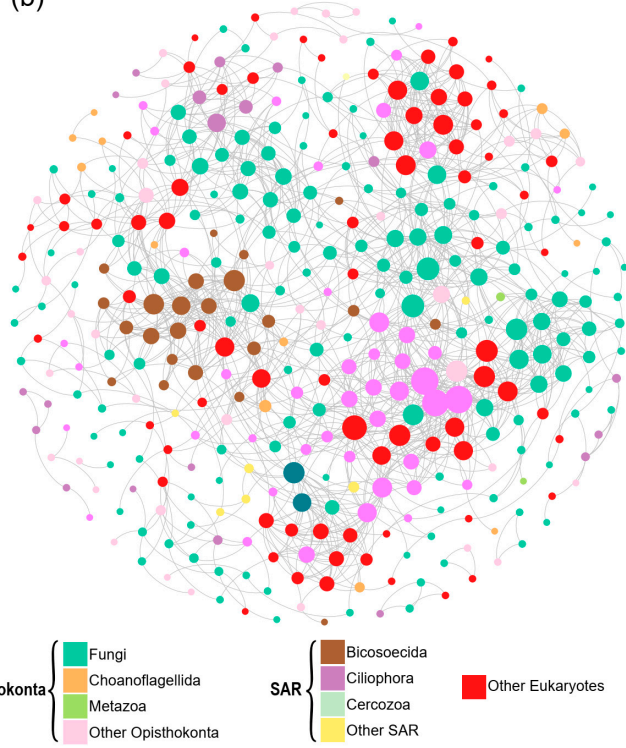

(d)

Figure 4. Co-occurrence networks of sediment and water microeukaryotic communities colored by $(\mathbf{a}, \mathbf{b})$ major taxonomic groups and (c,d) major modules (modules have more than 30 nodes). Nodes represent OTUs. Edges represent Spearman's correlations. Only strong (Spearman's R > 0.6 or $\mathrm{R}<-0.6)$ and significant ( $p<0.05, p$-values are adjusted using FDR methods) correlations are shown. The node size is proportional to the degree of the node.
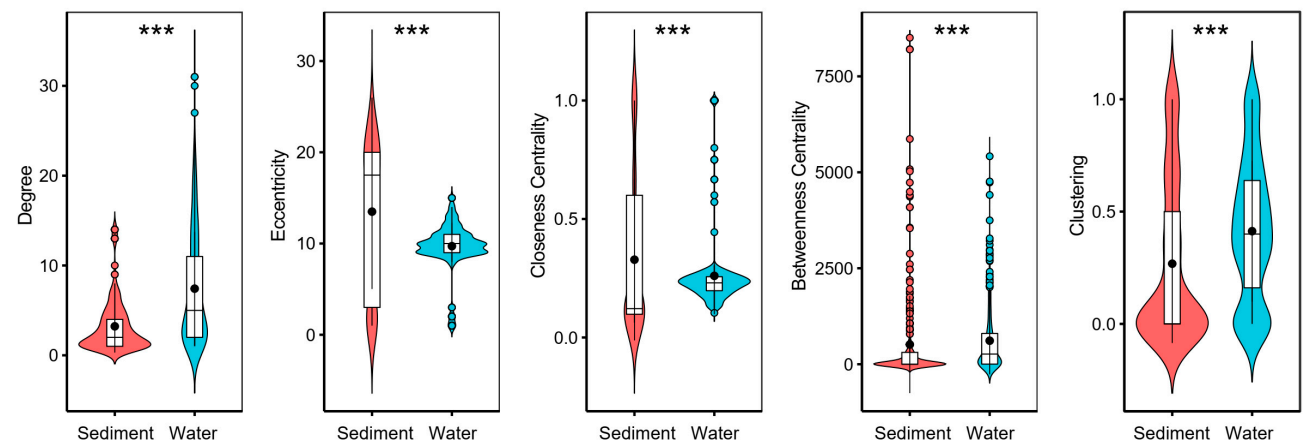

Figure 5. Node-level topological features of sediment and water microeukaryotic networks. The differences were tested using Wilcoxon rank-sum test $\left.{ }^{* * *} p<0.001\right)$ 
(a)

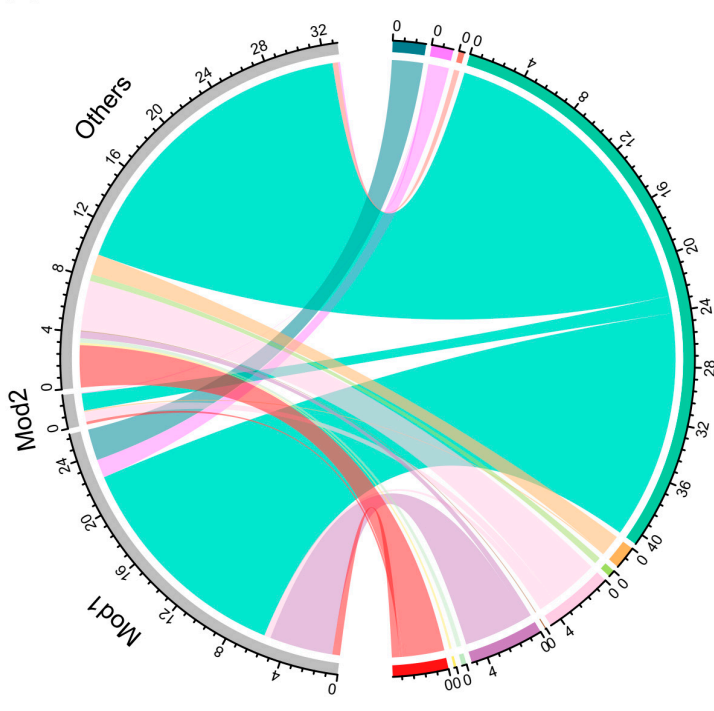

(b)

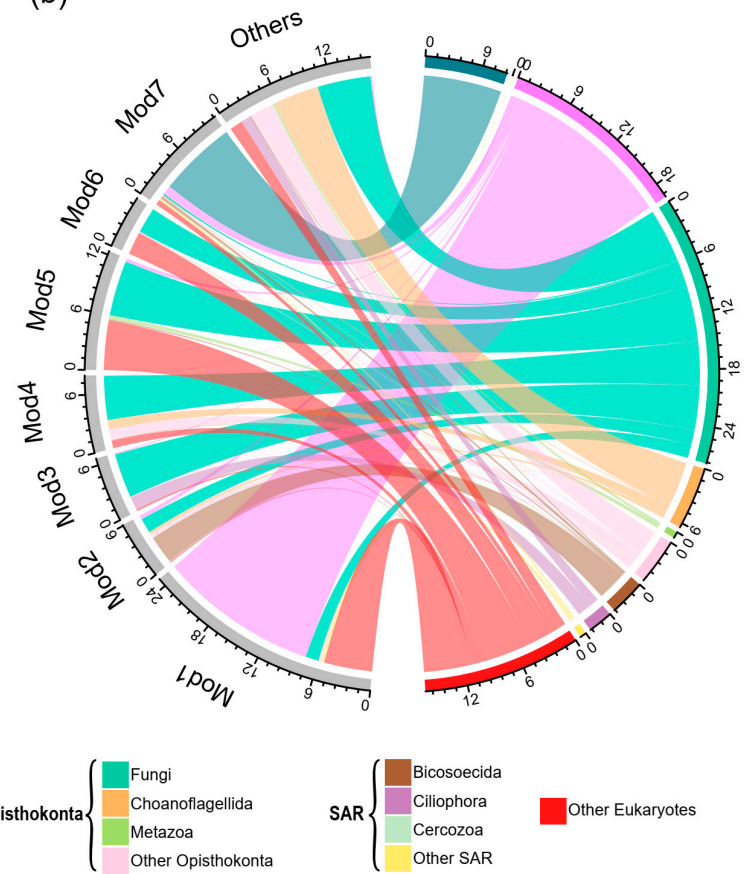

Figure 6. Taxonomic composition of modules in terms of relative abundance of OTUs in (a) sediment microeukaryotic network and (b) water microeukaryotic network.

\section{Discussion}

This study showed that microeukaryotic communities were significantly different in composition and structure between sediment and water in our studied thermokarst lakes (Figure 1c). Sediment microeukaryotic communities had significantly lower $\alpha$-diversity but higher $\beta$-diversity than water microeukaryotic communities (Figure 1). This pattern was consistent with our previous study of bacterial communities in the same lakes [11]. In lake ecosystems, distinct microorganisms inhabit in sediment and water [59-62]. Microeukaryotic communities were composed by various taxa and structured differently in sediment and water (Figure 2). A significantly higher mean value of $\beta$ MNTD for SMC indicates that microeukaryotes in sediment are less closely phylogenetically clustered than that in water [63]. Mantel test showed that $\mathrm{pH}, \mathrm{SOC}$, and TP were significantly associated to dissimilarities of microeukaryotic communities for sediment samples (Table 1), while conductivity was significant for water samples (Table 2). The environmental responses of microeukaryotic communities were different to bacterial communities which are more associated to nutrient factors [11].

Microeukaryotic community structure varies across different spatiotemporal scales and habitats $[17,21,23,24]$. Sediment and water harbor significantly different microbial communities $[42,64]$. Results of this study suggest that both sediment and water microeukaryotic communities are strongly governed by stochastic assembly processes, especially dispersal limitation (Figure 3). Microbial dispersal is typically considered as a passive process [27] where increasing community variations and turnover are coupled with environmental filtering $[65,66]$. A strong signal of dispersal limitation and a very low signal of homogenizing dispersal indicate that movements of microeukaryotes between thermokarst lakes are highly restricted. A potential explanation for the high dispersal limitation is that thermokarst lakes are unique habitats and lack of connections due to their endorheic nature, resulting in strong simultaneous environment filtering. Moreover, thermokarst lakes are frozen for prolonged periods within a year, rendering microorganisms frozen in place as well $[67,68]$. Although many microorganisms have a cosmopolitan distribution, their slow dispersal may allow for regional phylogenetic differences and endemic taxa to develop in isolated habitats, resulting in low probabilities for microorganisms to disperse to suitable 
distant sites [69]. Therefore, dispersal processes may be restricted by limited movement, short unfrozen time, and strong environmental filtering, leading to the high dispersal limitation observed in thermokarst lakes, even at a small regional scale. This result is supported by other studies showing the significant effect of dispersal limitation on the structuring of microbial communities in lakes [70-72]. A similar pattern of strong dispersal limitation is also found for bacterial communities in permafrost, whose thawing results in the formation of thermokarst lakes [73]. In addition, microeukaryotic communities in water were more governed by deterministic assembly processes, especially by homogenous selection, than those in sediment (Figure 3). Long-term evolution of the thermokarst lakes results in homogenized habitats and homogeneous selection was found to be a stronger driver of the assembly of WMC than SMC. In addition, stronger governance by deterministic processes also suggests that the microeukaryotic communities in water were more phylogenetically clustered than that in sediment, supported by the lower Bray-Curtis distance and $\beta M N T D$ of WMC than SWC (Figure 1).

Microeukaryotes typically co-occur with strong interactions in lake ecosystems [22,74,75], offering new insights into community assembly mechanisms by identifying potential interactions among microorganisms $[33,76]$. In our study, microeukaryotic communities in sediment and water constructed distinct co-occurrence networks in the studied thermokarst lakes. The results showed that the sediment and water microeukaryotic networks presented significantly different topological properties (Figures 4 and 5, and Table 3). The network-level properties of WMN, such as higher number of nodes and edges, average degree, clustering coefficient, and graph density, as well as lower average path, indicate that WMN was more complex and more interconnected than SMN. A similar pattern was also found for bacterial community networks in these lakes [42]. Moreover, microeukaryotic communities had a higher $\alpha$-diversity and lower $\beta$-diversity in water than in sediment, which is in accordance with the high complexity and interconnection of WMN. Higher taxa richness provides more probabilities for establishing interrelationships between each other [77]. Taxa also tend to co-occur at lower $\beta$-diversity because of high community similarity [42]. In addition, microeukaryotes had a higher niche width in water than in sediment (Figure S3), indicating that water microeukaryotes had stronger competition due to similar environmental preferences than sediment taxa. Species that have high competition or driven by the same environmental factors tend to have complex interactions with each other $[78,79]$, resulting in a complex co-occurrence network. However, compared to SMN, WMN might have a lower stability under disturbance due to its strong connectivity and high complexity [80-82], thus suggesting a higher vulnerability of WMN in the accelerated warming world.

More ecological information on microeukaryotic communities, such as synergistic and competitive interactions as well as niche differentiation $[83,84]$ can be uncovered by module structure of the networks $[85,86]$. SMN had a significantly higher modularity (the tendency of the network to contain modules) than WMN (Table 3), suggesting high habitat heterogeneity and niche diversity [62,87]. Moreover, WMN had a higher number of major modules (modules with more than 30 nodes) than SMN (Figure 4), suggesting that more taxa prefer similar environments and are functionally complementary [83,86]. Modules were dominated by different taxonomic groups (Figure 6). For SMN, the Mantel test showed that module1 was significantly associated with $\mathrm{pH}, \mathrm{SOC}$, and TP, while module2 was not significantly associated with any of the tested environmental variables (Table 1). For WMN, different modules responded differently to the environmental variables with module2 responding to all measured environmental variables and module 5 responding to none (Table 2). The relationships between microbial modules and environmental variables provide further understanding of environmental influences on microbial assemblages [88,89].

\section{Conclusions}

Thermokarst lakes are pervasive and important aquatic ecosystems in cold regions with high latitude and elevation, experiencing significant changes due to accelerated global 
warming. Assessing the assembly mechanisms and co-occurrence patterns of microeukaryotic communities in sediment and water is critical for understanding the structure and stability of thermokarst lake ecosystems in the warming world. Our study highlighted that microeukaryotic communities in sediment and water have distinct alpha diversity patterns, assembly mechanisms, co-occurrence patterns, and different responses to environmental variables. Microeukaryotes in sediment were less phylogenetically and taxonomically clustered than those in water. SOC, $\mathrm{pH}$, and TP were significant drivers of phylogenetic dissimilarities of microeukaryotic communities in sediment, while conductivity was significant driver for water microeukaryotic communities. Dispersal limitation was dominant in shaping microeukaryotic communities in both sediment and water. Moreover, deterministic assembly processes had a higher contribution to community assembly in water than that in sediment. Future changes in sediment TN and TP could shift assembly processes of sediment microeukaryotic communities. Water microeukaryotes are characterized by a highly complex and interconnected co-occurrence network with lower modularity than that of sediment microeukaryotes. It is expected that future climate change and permafrost degradation will impose different influences on sediment and water microeukaryotic communities in thermokarst lakes.

Supplementary Materials: The following supporting information can be downloaded at: https: / / www.mdpi.com/article/10.3390/microorganisms10020481/s1, Figure S1: Water and sediment samples were collected from 23 lakes in early July 2020 in the Yellow River Source Area on the Qinghai-Tibet Plateau. The map was cited from our previous research [11]; Figure S2: Flower plot diagram showing core and accessory OTUs across (a) all sediment and water samples, (b) all sediment samples, and (c) all water samples. The central circle shows the number of OTUs common to all samples while the petals show the number of OTUs in addition to the core set; Figure S3: Niche width of the taxa microeukaryotic communities of sediment and water. The difference was tested using Wilcoxon rank-sum test.

Author Contributions: Conceptualization, Z.R.; methodology, Z.R.; software, Z.R. and X.L.; validation, Z.R., K.M., X.J., Q.W., C.Z. and X.L.; formal analysis, Z.R. and K.M.; investigation, Z.R. and C.Z.; resources, Z.R.; data curation, Z.R.; writing-original draft preparation, Z.R.; writing—review and editing, Z.R., K.M., X.J., Q.W., C.Z. and X.L.; visualization, Z.R. and X.L.; supervision, Z.R.; project administration, Z.R.; funding acquisition, Z.R. and C.Z. All authors have read and agreed to the published version of the manuscript.

Funding: This study was supported by the start-up funding for the new introduced talents of the Beijing Normal University (28707-111032105) and the Guangdong Basic and Applied Basic Research Foundation (2021A1515010392).

Institutional Review Board Statement: Not applicable.

Informed Consent Statement: Not applicable.

Data Availability Statement: Raw sequence data can be accessed at the China National Center for Bioinformation (PRJCA005279).

Acknowledgments: We are grateful to Yongming Deng for his assistance in the field work.

Conflicts of Interest: The authors declare no conflict of interest.

\section{References}

1. Kokelj, S.V.; Jorgenson, M.T. Advances in Thermokarst Research. Permafr. Periglac. Process. 2013, 24, 108-119. [CrossRef]

2. Farquharson, L.M.; Mann, D.H.; Grosse, G.; Jones, B.M.; Romanovsky, V.E. Spatial distribution of thermokarst terrain in Arctic Alaska. Geomorphology 2016, 273, 116-133. [CrossRef]

3. Niu, F.; Lin, Z.; Liu, H.; Lu, J. Characteristics of thermokarst lakes and their influence on permafrost in Qinghai-Tibet Plateau. Geomorphology 2011, 132, 222-233. [CrossRef]

4. Luo, D.-L.; Jin, H.-J.; Dong-Liang, L.; Ma, Q.; Duan, S.-Q.; Li, G.-S. Variation of alpine lakes from 1986 to 2019 in the Headwater Area of the Yellow River, Tibetan Plateau using Google Earth Engine. Adv. Clim. Chang. Res. 2020, 11, 11-21. [CrossRef]

5. Veremeeva, A.; Nitze, I.; Günther, F.; Grosse, G.; Rivkina, E. Geomorphological and Climatic Drivers of Thermokarst Lake Area Increase Trend (1999-2018) in the Kolyma Lowland Yedoma Region, North-Eastern Siberia. Remote Sens. 2021, 13, 178. [CrossRef] 
6. Vincent, W.F.; Lemay, M.; Allard, M.; Wolfe, B.B. Adapting to Permafrost Change: A Science Framework. EOS 2013, 94, $373-375$. [CrossRef]

7. $\quad$ Biskaborn, B.K.; Smith, S.L.; Noetzli, J.; Matthes, H.; Vieira, G.; Streletskiy, D.A.; Schoeneich, P.; Romanovsky, V.E.; Lewkowicz, A.G.; Abramov, A.; et al. Permafrost is warming at a global scale. Nat. Commun. 2019, 10, 264. [CrossRef]

8. Luo, J.; Niu, F.; Lin, Z.; Liu, M.; Yin, G. Thermokarst lake changes between 1969 and 2010 in the Beilu River Basin, Qinghai-Tibet Plateau, China. Sci. Bull. 2015, 60, 556-564. [CrossRef]

9. Grosse, G.; Jones, B.M.; Arp, C.D. Thermokarst Lake, Drainage, and Drained Basins, in Treatise on Geomorphology; Shroder, J., Giardino, R., Harbor, J., Eds.; Elsevier Academic Press: San Diego, CA, USA, 2013; pp. 1-29.

10. Sepulveda-Jauregui, A.; Anthony, K.M.W.; Martinez-Cruz, K.; Greene, S.; Thalasso, F. Methane and carbon dioxide emissions from 40 lakes along a north-south latitudinal transect in Alaska. Biogeosciences 2015, 12, 3197-3223. [CrossRef]

11. Ren, Z.; Zhang, C.; Li, X.; Ma, K.; Cui, B. Abundant and rare bacterial taxa structuring differently in sediment and water in thermokarst lakes in the Yellow River Source area, Qinghai-Tibet Plateau. bioRxiv 2021, 445882. [CrossRef]

12. Toniolo, H.; Kodial, P.; Hinzman, L.; Yoshikawa, K. Spatio-temporal evolution of a thermokarst in Interior Alaska. Cold Reg. Sci. Technol. 2009, 56, 39-49. [CrossRef]

13. Niu, F.; Lin, Z.; Lu, J.; Luo, J.; Wang, H. Assessment of terrain susceptibility to thermokarst lake development along the Qinghai-Tibet engineering corridor, China. Environ. Earth Sci. 2014, 73, 5631-5642. [CrossRef]

14. Smith, L.C.; Sheng, Y.; Macdonald, G.M.; Hinzman, L.D. Disappearing Arctic Lakes. Science 2005, 308, 1429. [CrossRef]

15. Schaechter, M. Eukaryotic Microbes; Academic Press: Amsterdam, The Netherlands, 2012.

16. Salmaso, N.; Boscaini, A.; Pindo, M. Unraveling the Diversity of Eukaryotic Microplankton in a Large and Deep Perialpine Lake Using a High Throughput Sequencing Approach. Front. Microbiol. 2020, 11, 789. [CrossRef]

17. Pearman, J.K.; Biessy, L.; Thomson-Laing, G.; Waters, S.; Vandergoes, M.J.; Howarth, J.D.; Rees, A.; Moy, C.; Pochon, X.; Wood, S.A. Local factors drive bacterial and microeukaryotic community composition in lake surface sediment collected across an altitudinal gradient. FEMS Microbiol. Ecol. 2020, 96, fiaa070. [CrossRef]

18. Zubkov, M.V.; Tarran, G.A. High bacterivory by the smallest phytoplankton in the North Atlantic Ocean. Nature 2008, 455, 224-226. [CrossRef]

19. Sherr, B.; Sherr, E.; Caron, D.; Vaulot, D.; Worden, A. Oceanic Protists. Oceanography 2007, 20, 130-134. [CrossRef]

20. Hanson, C.A.; Fuhrman, J.A.; Horner-Devine, M.C.; Martiny, J.B.H. Beyond biogeographic patterns: Processes shaping the microbial landscape. Nat. Rev. Genet. 2012, 10, 497-506. [CrossRef]

21. Capo, E.; Ninnes, S.; Domaizon, I.; Bertilsson, S.; Bigler, C.; Wang, X.-R.; Bindler, R.; Rydberg, J. Landscape Setting Drives the Microbial Eukaryotic Community Structure in Four Swedish Mountain Lakes over the Holocene. Microorganisms 2021, 9, 355. [CrossRef]

22. Xue, Y.; Chen, H.; Yang, J.R.; Liu, M.; Huang, B.; Yang, J. Distinct patterns and processes of abundant and rare eukaryotic plankton communities following a reservoir cyanobacterial bloom. ISME J. 2018, 12, e2263. [CrossRef]

23. Coesel, S.N.; Durham, B.P.; Groussman, R.D.; Hu, S.K.; Caron, D.A.; Morales, R.L.; Ribalet, F.; Armbrust, E.V. Diel transcriptional oscillations of light-sensitive regulatory elements in open-ocean eukaryotic plankton communities. Proc. Natl. Acad. Sci. USA 2021, 118, e2011038118. [CrossRef] [PubMed]

24. Simon, M.; López-García, P.; Deschamps, P.; Moreira, D.; Restoux, G.; Bertolino, P.; Jardillier, L. Marked seasonality and high spatial variability of protist communities in shallow freshwater systems. ISME J. 2015, 9, 1941-1953. [CrossRef] [PubMed]

25. Stegen, J.C.; Lin, X.; Fredrickson, J.K.; Chen, X.; Kennedy, D.W.; Murray, C.J.; Rockhold, M.L.; Konopka, A. Quantifying communi-ty assembly processes and identifying features that impose them. ISME J. 2013, 7, 2069-2079. [CrossRef] [PubMed]

26. Zhou, J.; Ning, D. Stochastic Community Assembly: Does It Matter in Microbial Ecology? Microbiol. Mol. Biol. Rev. 2017, 81, e00002-17. [CrossRef]

27. Nemergut, D.R.; Schmidt, S.K.; Fukami, T.; O’Neill, S.P.; Bilinski, T.M.; Stanish, L.F.; Knelman, J.E.; Darcy, J.L.; Lynch, R.C.; Wickey, P.; et al. Patterns and Processes of Microbial Community Assembly. Microbiol. Mol. Biol. Rev. 2013, 77, 342-356. [CrossRef]

28. Chase, J.M. Stochastic Community Assembly Causes Higher Biodiversity in More Productive Environments. Science 2010, 328, 1388-1391. [CrossRef]

29. Zhou, J.; Deng, Y.; Zhang, P.; Xue, K.; Liang, Y.; Van Nostrand, J.; Yang, Y.; He, Z.; Wu, L.; Stahl, D.A.; et al. Stochasticity, succession, and environmental perturbations in a fluidic ecosystem. Proc. Natl. Acad. Sci. USA 2014, 111, E836-E845. [CrossRef]

30. Chave, J. Neutral theory and community ecology. Ecol. Lett. 2004, 7, 241-253. [CrossRef]

31. Aguilar, P.; Sommaruga, R. The balance between deterministic and stochastic processes in structuring lake bacterioplankton community over time. Mol. Ecol. 2020, 29, 3117-3130. [CrossRef] [PubMed]

32. Stegen, J.; Lin, X.; Konopka, A.; Fredrickson, J.K. Stochastic and deterministic assembly processes in subsurface microbial communities. ISME J. 2012, 6, 1653-1664. [CrossRef]

33. Fuhrman, J.A. Microbial community structure and its functional implications. Nature 2009, 459, 193-199. [CrossRef]

34. Gotelli, N.J.; Mccabe, D.J. Species co-occurrence: A meta-analysis of J. M. Diamond's assembly rules model. Ecology 2002, 83, 2091-2096. [CrossRef]

35. Banerjee, S.; Schlaeppi, K.; Van Der Heijden, M.G.A. Keystone taxa as drivers of microbiome structure and functioning. Nat. Rev. Microbiol. 2018, 16, 567-576. [CrossRef] 
36. Layeghifard, M.; Hwang, D.M.; Guttman, D.S. Disentangling Interactions in the Microbiome: A Network Perspective. Trends Microbiol. 2017, 25, 217-228. [CrossRef]

37. Carter, J.L.; Topping, B.R.; Kuwabara, J.S.; Balistrieri, L.S.; Woods, P.F.; Berelson, W.M.; Fend, S.V. Importance of Sediment? Water Interactions in Coeur Alene Lake, Idaho, USA: Management Implications. Environ. Manag. 2003, 32, 348-359. [CrossRef]

38. Parker, S.R.; West, R.F.; Boyd, E.S.; Feyhl-Buska, J.; Gammons, C.H.; Johnston, T.B.; Williams, G.P.; Poulson, S.R. Biogeochemical and microbial seasonal dynamics between water column and sediment processes in a productive mountain lake: Georgetown Lake, MT, USA. J. Geophys. Res. Biogeosci. 2016, 121, 2064-2081. [CrossRef]

39. Serikova, S.; Pokrovsky, O.S.; Laudon, H.; Krickov, I.V.; Lim, A.G.; Manasypov, R.M.; Karlsson, J. High carbon emissions from thermokarst lakes of Western Siberia. Nat. Commun. 2019, 10, 1552. [CrossRef]

40. Manasypov, R.M.; Pokrovsky, O.S.; Shirokova, L.S.; Auda, Y.; Zinner, N.S.; Vorobyev, S.N.; Kirpotin, S.N. Biogeochemistry of macrophytes, sediments and porewaters in thermokarst lakes of permafrost peatlands, western Siberia. Sci. Total Environ. 2021, 763, 144201. [CrossRef]

41. Kokelj, S.V.; Jenkins, R.E.; Milburn, D.; Burn, C.R.; Snow, N. The influence of thermokarst disturbance on the water quality of small upland lakes, Mackenzie Delta region, Northwest Territories, Canada. Permafr. Periglac. Process. 2005, 16, $343-353$. [CrossRef]

42. Ren, Z.; Zhang, C.; Li, X.; Ma, K.; Zhang, Z.; Feng, K.; Cui, B. Bacterial communities present distinct co-occurrence net-works in sediment and water of the thermokarst lakes in the Yellow River Source Area. Front. Microbiol. 2021, 12, e716732. [CrossRef]

43. Qiu, J. China: The third pole. Nature 2008, 454, 393-396. [CrossRef]

44. Yao, T.; Thompson, L.G.; Mosbrugger, V.; Zhang, F.; Ma, Y.; Luo, T.; Xu, B.; Yang, X.; Joswiak, D.R.; Wang, W.; et al. Third Pole Environment (TPE). Environ. Dev. 2012, 3, 52-64. [CrossRef]

45. Qin, Y.; Yang, D.; Gao, B.; Wang, T.; Chen, J.; Chen, Y.; Wang, Y.; Zheng, G. Impacts of climate warming on the frozen ground and eco-hydrology in the Yellow River source region, China. Sci. Total Environ. 2017, 605-606, 830-841. [CrossRef]

46. Zhang, G.; Yao, T.; Piao, S.; Bolch, T.; Xie, H.; Chen, D.; Gao, Y.; O’Reilly, C.M.; Shum, C.K.; Yang, K.; et al. Extensive and drastically different alpine lake changes on Asia's high plateaus during the past four decades. Geophys. Res. Lett. 2017, 44, 252-260. [CrossRef]

47. Zheng, H.; Zhang, L.; Liu, C.; Shao, Q.; Fukushima, Y. Changes in stream flow regime in headwater catchments of the Yellow River basin since the 1950s. Hydrol. Process. 2007, 21, 886-893. [CrossRef]

48. Hu, Y.; Maskey, S.; Uhlenbrook, S. Trends in temperature and rainfall extremes in the Yellow River source region, China. Clim. Chang. 2012, 110, 403-429. [CrossRef]

49. Li, J.; Sheng, Y.; Wu, J.; Feng, Z.; Ning, Z.; Hu, X.; Zhang, X. Landform-related permafrost characteristics in the source area of the Yellow River, eastern Qinghai-Tibet Plateau. Geomorphology 2016, 269, 104-111. [CrossRef]

50. Dancer, W.S.; Eliason, R.; Lekhakul, S. Microwave assisted soil and waste dissolution for estimation of total phosphorus. Commun. Soil Sci. Plant Anal. 1998, 29, 1997-2006. [CrossRef]

51. Caporaso, J.G.; Kuczynski, J.; Stombaugh, J.; Bittinger, K.; Bushman, F.D.; Costello, E.K.; Fierer, N.; Peña, A.G.; Goodrich, J.K.; Gordon, J.I.; et al. QIIME allows analysis of high-throughput community sequencing data. Nat. Methods 2010, 7, 335-336. [CrossRef]

52. Quast, C.; Pruesse, E.; Yilmaz, P.; Gerken, J.; Schweer, T.; Yarza, P.; Peplies, J.; Glöckner, F.O. The SILVA ribosomal RNA gene database project: Improved data processing and web-based tools. Nucleic Acids Res. 2013, 41, 590-596. [CrossRef]

53. Kembel, S.W.; Cowan, P.D.; Helmus, M.R.; Cornwell, W.K.; Morlon, H.; Ackerly, D.D.; Blomberg, S.P.; Webb, C.O. Picante: R tools for integrating phylogenies and ecology. Bioinformatics 2010, 26, 1463-1464. [CrossRef]

54. Benjamini, Y.; Hochberg, Y. Controlling the False Discovery Rate: A Practical and Powerful Approach to Multiple Testing. J. R. Stat. Soc. Ser. B 1995, 57, 289-300. [CrossRef]

55. Csardi, M.G. Package 'Igraph'. 2013. Available online: https://cran.r-project.org/web/packages/igraph/index.html (accessed on 1 August 2021).

56. Levins, R. Evolution in Changing Environments: Some Theoretical Explorations (No. 2); Princeton University Press: Princeton, NJ, USA, 1968

57. Zhang, J.L. Species Association Analysis, Version 0.2.2. 2016. Available online: https://CRAN.R-project.org/package=spaa (accessed on 1 August 2021).

58. R Core Team. R: A Language and Environment for Statistical Computing; R Foundation for Statistical Computing: Vienna, Austria, 2012.

59. Briée, C.; Moreira, D.; Lopez-Garcia, P. Archaeal and bacterial community composition of sediment and plankton from a suboxic freshwater pond. Res. Microbiol. 2007, 158, 213-227. [CrossRef]

60. Gough, H.L.; Stahl, D. Microbial community structures in anoxic freshwater lake sediment along a metal contamination gradient. ISME J. 2010, 5, 543-558. [CrossRef]

61. Yang, J.; Ma, L.; Jiang, H.; Wu, G.; Dong, H. Salinity shapes microbial diversity and community structure in surface sediments of the Qinghai-Tibetan Lakes. Sci. Rep. 2016, 6, e25078. [CrossRef]

62. Ren, Z.; Wang, F.; Qu, X.; Elser, J.J.; Liu, Y.; Chu, L. Taxonomic and Functional Differences between Microbial Communities in Qinghai Lake and Its Input Streams. Front. Microbiol. 2017, 8, 2319. [CrossRef]

63. Langenheder, S.; Wang, J.; Karjalainen, S.M.; Laamanen, T.M.; Tolonen, K.T.; Vilmi, A.; Heino, J. Bacterial metacommunity or-ganization in a highly connected aquatic system. FEMS Microbiol. Ecol. 2017, 93, fiw225. 
64. Ren, Z.; Qu, X.; Peng, W.; Yu, Y.; Zhang, M. Nutrients Drive the Structures of Bacterial Communities in Sediments and Surface Waters in the River-Lake System of Poyang Lake. Water 2019, 11, 930. [CrossRef]

65. Cline, L.C.; Zak, D.R. Dispersal limitation structures fungal community assembly in a long-term glacial chronosequence. Environ. Microbiol. 2014, 16, 1538-1548. [CrossRef]

66. Stegen, J.C.; Lin, X.; Fredrickson, J.K.; Konopka, A.E. Estimating and mapping ecological processes influencing microbial community assembly. Front. Microbiol. 2015, 6, 370. [CrossRef]

67. Vigneron, A.; Lovejoy, C.; Cruaud, P.; Kalenitchenko, D.; Culley, A.; Vincent, W.F. Contrasting Winter Versus Summer Microbial Communities and Metabolic Functions in a Permafrost Thaw Lake. Front. Microbiol. 2019, 10, 1656. [CrossRef]

68. Vargas Medrano, M. Recent Changes in the Zooplankton Communities of Arctic Tundra Ponds in Response to Warmer Temperatures and Nutrient Enrichment. Ph.D. Thesis, University of Texas at El Paso, El Paso, TX, USA, 2019.

69. Telford, R.J.; Vandvik, V.; Birks, H.J.B. Dispersal Limitations Matter for Microbial Morphospecies. Science 2006, 312,1015 [CrossRef]

70. Yang, J.; Jiang, H.; Dong, H.; Liu, Y. A comprehensive census of lake microbial diversity on a global scale. Sci. China Life Sci. 2019, 62, 1320-1331. [CrossRef]

71. Liu, K.; Yao, T.; Pearce, D.A.; Jiao, N.; Zeng, Y.; Guo, B.; Liu, Y. Bacteria in the lakes of the Tibetan Plateau and polar regions. Sci. Total Environ. 2021, 754, 142248. [CrossRef]

72. Lindström, E.S.; Langenheder, S. Local and regional factors influencing bacterial community assembly. Environ. Microbiol. Rep. 2011, 4, 1-9. [CrossRef]

73. Bottos, E.M.; Kennedy, D.W.; Romero, E.B.; Fansler, S.J.; Brown, J.M.; Bramer, L.M.; Chu, R.K.; Tfaily, M.; Jansson, J.; Stegen, J.C. Dispersal limitation and thermodynamic constraints govern spatial structure of permafrost microbial communities. FEMS Microbiol. Ecol. 2018, 94, fiy110. [CrossRef]

74. Liu, Y.; Ren, Z.; Qu, X.; Zhang, M.; Yu, Y.; Peng, W. Seasonal Water Level Fluctuation and Concomitant Change of Nutrients Shift Microeukaryotic Communities in a Shallow Lake. Water 2020, 12, 2317. [CrossRef]

75. Mikhailov, I.S.; Zakharova, Y.R.; Bukin, Y.S.; Galachyants, Y.P.; Petrova, D.; Sakirko, M.V.; Likhoshway, Y.V. Co-occurrence Networks Among Bacteria and Microbial Eukaryotes of Lake Baikal During a Spring Phytoplankton Bloom. Microb. Ecol. 2019, 77, 96-109. [CrossRef]

76. Ren, Z.; Gao, H. Ecological networks reveal contrasting patterns of bacterial and fungal communities in glacier-fed streams in Central Asia. PeerJ 2019, 7, e7715. [CrossRef]

77. Tu, Q.; Yan, Q.; Deng, Y.; Michaletz, S.T.; Buzzard, V.; Weiser, M.D.; Waide, R.; Ning, D.; Wu, L.; He, Z.; et al. Biogeographic patterns of microbial co-occurrence ecological networks in six American forests. Soil Biol. Biochem. 2020, 148, 107897. [CrossRef]

78. Levy, R.; Borenstein, E. Metabolic modeling of species interaction in the human microbiome elucidates community-level assembly rules. Proc. Natl. Acad. Sci. USA 2013, 110, 12804-12809. [CrossRef] [PubMed]

79. Liu, J.; Meng, Z.; Liu, X.; Zhang, X.H. Microbial assembly, interaction, functioning, activity and diversification: A review de-rived from community compositional data. Mar. Life Sci. Technol. 2019, 1, 112-128. [CrossRef]

80. Mccann, K.S. The diversity-stability debate. Nature 2000, 405, 228-233. [CrossRef] [PubMed]

81. Kara, E.L.; Hanson, P.C.; Hu, Y.H.; Winslow, L.; McMahon, K.D. A decade of seasonal dynamics and co-occurrences within freshwater bacterioplankton communities from eutrophic Lake Mendota, WI, USA. ISME J. 2012, 7, 680-684. [CrossRef]

82. de Vries, F.T.; Griffiths, R.I.; Bailey, M.; Craig, H.; Girlanda, M.; Gweon, H.S.; Hallin, S.; Kaisermann, A.; Keith, A.M.; Kretzschmar, M.; et al. Soil bacterial networks are less stable under drought than fungal networks. Nat. Commun. 2018, 9, 3033. [CrossRef] [PubMed]

83. Freedman, Z.B.; Zak, D.R. Atmospheric $\mathrm{N}$ deposition alters connectance, but not functional potential among saprotrophic bacterial communities. Mol. Ecol. 2015, 24, 3170-3180. [CrossRef]

84. Olesen, J.M.; Bascompte, J.; Dupont, Y.L.; Jordano, P. The modularity of pollination networks. Proc. Natl. Acad. Sci. USA 2007, 104, 19891-19896. [CrossRef] [PubMed]

85. Thompson, J.N. The Geographic Mosaic of Coevolution; University of Chicago Press: Chicago, IL, USA, 2005.

86. Newman, M.E.J. Modularity and community structure in networks. Proc. Natl. Acad. Sci. USA 2006, 103, 8577-8582. [CrossRef] [PubMed]

87. Barberan, A.; Bates, S.T.; Casamayor, E.O.; Fierer, N. Using network analysis to explore co-occurrence patterns in soil micro-bial communities. ISME J. 2012, 6, 343-351. [CrossRef] [PubMed]

88. De Menezes, A.B.; Prendergast-Miller, M.; Richardson, A.E.; Toscas, P.; Farrell, M.; Macdonald, L.; Baker, G.; Wark, T.; Thrall, P.H. Network analysis reveals that bacteria and fungi form modules that correlate independently with soil parameters. Environ. Microbiol. 2015, 17, 2677-2689. [CrossRef]

89. Toju, H.; Kishida, O.; Katayama, N.; Takagi, K. Networks Depicting the Fine-Scale Co-Occurrences of Fungi in Soil Horizons. PLOS ONE 2016, 11, e0165987. [CrossRef] [PubMed] 